\title{
Diet composition of Angora goats in a short-duration graz- ing system
}

CHARLES A. TAYLOR, JR., AND MERWYN M. KOTHMANN

\begin{abstract}
Botanical and chemical compositions of Angora gont (Capra hircus) diets, determined with esophageally cannulated animals, were studied with and independent of a cattle-sheep-goat herd in a short-duration grazing (SDG) system. The study site consisted of 2 pastures in a 14-pasture, 1-herd SDG system. Each collection period in both pastures began when 44 animal units of livestock moved into either pasture 1 or 2 . This methodology allowed a comparison of diet selection with and without grazing pressure. Goats selected more grass during the summer and fall than during the winter and spring. Browse was preferred over grass and forbs. Generally, higher crude protein values tended to be associated with large amounts of browse and forb selection. In vitro digestibility was highest in April and lowest in August. Crude protein was highest in April and lowest in November. Under this particular stocking rate (.19 animal unit years/ha) and weather conditions, we concluded that increased grazing pressure, caused by a 4-day graze period in a SDG system, had little effect on goat nutrition.
\end{abstract}

Key Words: Angora goats, short duration grazing, foraging strutegies

Texas is the leading goat and mohair-producing state in the United States, providing $88 \%$ of the U.S. mohair supply and $30 \%$ of the world production. The goat's primary range in Texas is the Edwards Plateau, a geological uplift stretching across the south central and south western parts of the state.

Angora goat producers encounter many problems, (i.e., low fleece weights, poor reproduction, predator loss, disease, internal parasitism, and hypothermia), most of which are associated with sub-optimal nutritional levels (Huston et al. 1971). However, Angora goats are useful to manipulate range vegetation and to provide income to ranchers and meat and fiber to society. Goats graze more diverse kinds of vegetation and distribute themselves more evenly than cattle or sheep (Merrill and Taylor 1975).

Short-duration grazing systems (SDG) have been used as a part of grazing management in the Edwards Plateau for the past 18 years. Interest in SDG has been increased by Savory (1979), who reported that his grazing method permits safely doubling or tripling conventional stocking rates on rangelands. Since SDG is a part of grazing management on Edwards Plateau rangelands, there is a need to measure Angora goat response to the different physiological stresses it can create.

We investigated effects of time of year and presence or absence of the grazing herd on composition of Angora goat diets in a SDG system. We also measured the change of diet quality and quantity during the stay in a short-duration grazing system pasture.

\section{Study Area and Methods}

The study was conducted on the Texas Agricultural Experiment Station near Sonora, Texas. The study site consisted of two 16.5-ha

\footnotetext{
Authors are presently research station superintendent, Texas Agricultural Experiment Station, Sonora; and professor, Texas Agricultural Experiment Station and Department of Range Science, Texas A\&M University, College Station, respectively.

The assistance of J.E. Huston and Ray Hinnant is gratefully acknowledged. Published with approval of the Director, Texas Agricultural Experiment Station as TA-24307.

Manuscript accepted 24 April 1989.
}

paddocks in a 14-pasture, 1-herd, SDG system with a set stocking rate of $.19 \mathrm{AUY} /$ ha (AUY = Animal Unit Year). The 2 study pastures had originally been one 32.4-ha pasture that was split into 2 pastures approximately 1 year prior to this study. These 2 pastures were chosen because they seemed to be very similar with regards to topography and species composition. Diets could be selected without being affected by pasture differences and would represent a true measurement of the effects of grazing pressure on diet selection. Soils were Tarrant Stony Clays classified as a Low Stony Hill range site. Topographical, climatological, and vegetational characteristics were described by Smeins et al. (1976). Pastures in the SDG system were grazed for 3 and 4 days and rested for 42 to 50 days. The grazing herd consisted of 20 cows, 58 sheep, and 70 goats. Each 4-day collection period began when a herd of 44 animal units of livestock was moved into either paddock 1 or 2 . Four esophageally cannulated adult Angora goats per pasture, weighing approximately $36 \mathrm{~kg}$, were used to collect representative diet samples from the paddock in which the herd was grazing and the adjacent paddock. During each sampling period, diets were collected simultaneously in each of the 2 paddocks for 4 consecutive days. The cannulated goats were maintained in the SDG system throughout the year and randomly selected for the 2 treatments prior to each collection period. Available vegetation within the SDG pastures was determined before each 4-day esophageal collection period using a method described by Anderson and Kothmann (1982).

Botanical composition, based on percent of plant fragments, was divided into 3 major forage classes (grass, forb, and browse) (Durham and Kothmann 1977). Selection values for plant groups were developed from the diet data and available forage data (Taylor et al. 1980). The formula used in developing these ratings was as follows:

$$
\text { Selection value }=\frac{(\% \text { in diet }-\% \text { available })}{(\% \text { in diet }+\% \text { available })} \times 10
$$

A selection value of +10 indicates the highest possible value while a -10 indicates the lowest possible value and a 0 represents selection in proportion to availability.

Diet samples were frozen and freeze-dried prior to chemical analysis. All samples were ground through a Wiley mill fitted with a 1-mm screen. Chemical analyses included crude protein by the micro-Kjeldahl method (AOAC 1970) and in vitro organic matter digestibility (IVOMD) determined by a modified Van Soest procedure (Van Soest and Wine 1967).

Total feces were collected from 5 mature castrates grazing with the herd for 3 consecutive days during each collection period, using fecal bags supported by a single strap glued to the mohair on the back of animals. Fecal bags were emptied at $24-\mathrm{hr}$ intervals. Fecal samples were oven-dried at $60^{\circ} \mathrm{C}$, ground to pass through a $1-\mathrm{mm}$ screen in a Wiley mill and analyzed for total nitrogen using the micro-Kjeldahl method (AOAC).

Total intake was determined for goats grazing with the herd 
using the equation:

$$
\text { Intake }=\frac{100 \times \text { feces weight }}{100-\% \text { in vitro digestibility }}
$$

The grazing pressure index (GPI) was calculated for each pasture at each sampling period (Scarnecchia and Kothmann 1982). Because the sampling periods were only 4 days, growth was ignored and standing crop before grazing was used as the estimate of forage availability. Forage demand was the estimated total potential intake of the grazing herd during the 4-day sampling period.

For statistical treatment and data summary, plant species were categorized into 3 major classes of grasses, forbs, and browse. Pricklypear (Opuntia spp.), sacahuista (Nolina texana) and all yucca (Yucca spp.) were categorized as browse. Botanical and chemical constituents of diets were analyzed statistically using analysis of varience. Main effects were pastures, periods, days, and their interaction. Error terms for treatments were the variation among animals within pastures and the pastures by period interaction. Differences were evaluated using Duncan's multiple range test at $P<0.05$ (Steel and Torrie 1980).

\section{Results and Discussion}

\section{Available Forage}

Approximately 85 plant species were present in amounts adequate to justify quantitative measurement. There were approximately 20 different species of grasses, 30 species of forbs, and 19 species of browse. Curlymesquite (Hilaria belangeri (Steud.) Nash), sideoats grama (Bouteloua curtipendula (Michx.), and threeawn (Aristida spp.) were the major grasses in pasture 1 and 2. Bitterweed (Hymenoxys odorata D.C.) and other annual forbs represented the largest forb components in both study pastures. Orange zexmenia (Zexmenia hispida H.B.K.) was the dominant warm-season perennial forb. Juniper (Juniperus spp.), live oak (Quercus virginiana Mill.), and sacahuista (Nolina texana S. Wats.) were the major browse species in pastures 1 and 2.

Standing crop in pastures 1 and 2 more than doubled from February to April (Table 1). This was due to optimum soil moisture conditions and initiation of warm-season perennial grass growth. Between April and July, standing crop decreased, increased to April levels by August, then declined in October and November. Forb standing crop represented about $30 \%$ of the vegetation in February (Table 1). This was extremely high compared to other studies on the Sonora Experiment Station. Bryant (1977) and Malechek (1970) both reported that forbs represented less than $1 \%$ of the standing vegetation in February. Forb standing crop was highest in April and lowest in November. Bryant (1977) reported that orange zexmenia accounted for $50 \%$ of the total forb weight in August, but it represented a much smaller percentage in this study.

Most of the forbs were annuals. Forb standing crop declined after April in both pastures as the result of maturation and weathering.

Standing crop of browse was very similar between pastures 1 and 2 (Table 1). The general trend for browse was an increase in standing crop from February until July, and then a gradual decrease from July until November. Generally browse represented a small percentage of the available vegetation. This was especially true for April, during spring leaf drop for live oak. Also, pastures 1 and 2 had been previously continuously grazed by goats and had well-defined browsed lines.

\section{Botanical Composition of Diets}

Grass made up an average of $64 \%$ of goat diets over the study period (Table 2). This was higher grass consumption by goats than expected and probably resulted because of favorable precipitation and short rest periods between collection periods. These 2 factors kept grass in an immature growth stage throughout most of the growing season.

Goats selected higher amounts of grass $(P<.05)$ in pasture 2 $(70 \%)$ than in pasture $1(59 \%)$, whether or not they were grazing with the herd (Table 1). Grass selection by period varied from a low of $46 \%$ in February to a high of $77 \%$ in November (Table 2). This seasonal trend in grass selection was similar to that found by Malechek (1970) and Bryant (1977). They reported that goats selected roughly 50 to $60 \%$ grass during summer and fall. Provided adequate soil moisture is present, the major growth of warmseason grasses occurs in summer and early fall. This is when the immature parts of grass plants are readily selected by goats. Selection values for grass differed among collection periods, from a high of 1.6 in July to a low of -1.1 in April. Generally grass was consumed nearly in proportion to its availability.

\begin{tabular}{|c|c|c|c|c|c|c|c|c|c|c|c|c|c|c|}
\hline & \multicolumn{7}{|c|}{-Paddock 1} & \multicolumn{7}{|c|}{ Paddock 2- } \\
\hline & Feb & Apr & Jul & Aug & Oct & Nov & Mean & Feb & Apr & Jul & Aug & Oct & Nov & Mean \\
\hline Standing crop, $\mathrm{kg} / \mathrm{ha}$ & 433 & 1021 & 623 & 884 & 524 & 590 & - & 520 & 802 & 687 & 1045 & 621 & 432 & - \\
\hline GPI & $<.01$ & 0.27 & 0.45 & 0.31 & $<.01$ & 0.47 & - & 0.53 & $<.01$ & $<.01$ & $<.01$ & 0.45 & $<.01$ & - \\
\hline Herd present? & no & yes & yes & yes & no & yes & - & yes & no & no & no & yes & no & - - \\
\hline $\begin{array}{l}\text { Grass, \% in diet } \\
\text { Standard deviation } \\
\% \text { in standing crop }\end{array}$ & $\begin{array}{l}38 \\
10 \\
52\end{array}$ & $\begin{array}{r}44 \\
9 \\
60\end{array}$ & $\begin{array}{r}71 \\
3 \\
53\end{array}$ & $\begin{array}{l}62 \\
15 \\
81\end{array}$ & $\begin{array}{l}71 \\
13 \\
77\end{array}$ & $\begin{array}{r}72 \\
8 \\
88\end{array}$ & $\begin{array}{r}59 \\
-69\end{array}$ & $\begin{array}{l}53 \\
15 \\
47\end{array}$ & $\begin{array}{l}54 \\
13 \\
62\end{array}$ & $\begin{array}{l}77 \\
11 \\
54\end{array}$ & $\begin{array}{r}76 \\
7 \\
87\end{array}$ & $\begin{array}{r}81 \\
7 \\
83\end{array}$ & $\begin{array}{r}82 \\
7 \\
87\end{array}$ & $\frac{70}{70}$ \\
\hline $\begin{array}{l}\text { Forbs, } \% \text { in diet } \\
\text { Standard deviation } \\
\% \text { in standing crop }\end{array}$ & $\begin{array}{l}46 \\
18 \\
30\end{array}$ & $\begin{array}{r}14 \\
6 \\
28\end{array}$ & $\begin{array}{r}3 \\
3 \\
27\end{array}$ & $\begin{array}{r}4 \\
3 \\
14\end{array}$ & $\begin{array}{l}13 \\
10 \\
15\end{array}$ & $\begin{array}{l}2 \\
3 \\
5\end{array}$ & $\frac{14}{20}$ & $\begin{array}{l}42 \\
16 \\
27\end{array}$ & $\begin{array}{r}17 \\
9 \\
27\end{array}$ & $\begin{array}{r}5 \\
9 \\
23\end{array}$ & $\begin{array}{l}2 \\
4 \\
6\end{array}$ & $\begin{array}{l}3 \\
6 \\
9\end{array}$ & $\begin{array}{l}3 \\
1 \\
6\end{array}$ & $\frac{12}{16}$ \\
\hline $\begin{array}{l}\text { Browse, \% in diet } \\
\text { Standard deviation } \\
\% \text { in standing crop }\end{array}$ & $\begin{array}{r}15 \\
9 \\
4\end{array}$ & $\begin{array}{r}43 \\
14 \\
1\end{array}$ & $\begin{array}{r}27 \\
4 \\
7\end{array}$ & $\begin{array}{r}34 \\
15 \\
3\end{array}$ & $\begin{array}{r}19 \\
5 \\
4\end{array}$ & $\begin{array}{r}28 \\
7 \\
6\end{array}$ & $\frac{27}{4}$ & $\begin{array}{r}5 \\
16 \\
11\end{array}$ & $\begin{array}{r}29 \\
19 \\
1\end{array}$ & $\begin{array}{r}18 \\
8 \\
11\end{array}$ & $\begin{array}{r}22 \\
6 \\
5\end{array}$ & $\begin{array}{r}17 \\
7 \\
5\end{array}$ & $\begin{array}{r}13 \\
5 \\
5\end{array}$ & $-\frac{18}{6}$ \\
\hline $\begin{array}{l}\mathrm{CP}, \% \text { in diet } \\
\text { Standard deviation }\end{array}$ & $\begin{array}{r}16 \\
2\end{array}$ & $\begin{array}{r}20 \\
2\end{array}$ & $\begin{array}{r}12 \\
1\end{array}$ & $\begin{array}{r}10 \\
1\end{array}$ & $\begin{array}{l}9 \\
1\end{array}$ & $\begin{array}{r}10 \\
1\end{array}$ & 13 & $\begin{array}{r}14 \\
1\end{array}$ & $\begin{array}{r}19 \\
2\end{array}$ & $\begin{array}{r}13 \\
1\end{array}$ & $\begin{array}{r}10 \\
1\end{array}$ & $\begin{array}{r}11 \\
1\end{array}$ & $\begin{array}{r}11 \\
1\end{array}$ & 13 \\
\hline $\begin{array}{l}\text { IVOMD, \% in diet } \\
\text { Standard deviation }\end{array}$ & $\begin{array}{r}60 \\
2\end{array}$ & $\begin{array}{r}72 \\
2\end{array}$ & $\begin{array}{r}67 \\
2\end{array}$ & $\begin{array}{r}56 \\
1\end{array}$ & $\begin{array}{r}63 \\
2\end{array}$ & $\begin{array}{r}64 \\
3\end{array}$ & 64 & $\begin{array}{r}64 \\
3\end{array}$ & $\begin{array}{r}71 \\
1\end{array}$ & $\begin{array}{r}67 \\
2\end{array}$ & $\begin{array}{r}59 \\
2\end{array}$ & $\begin{array}{r}64 \\
1\end{array}$ & $\begin{array}{r}64 \\
3\end{array}$ & 65 \\
\hline
\end{tabular}

Table 1. Standing crop; grazing pressure index (GPI); percentages of grass, forbs, browse (including acorns), crude protein (CP), and in vitro organic matter digestibility (IVOMD) in goat diets with herd present or absent; and percentages of grass, forbs, and browse in standing crop. 
Table 2. Grass, forbs, browse (including acorns), crude protein (CP), and in vitro digestible organic matter (IVOMD) of goat diets, selection indexes, dry matter intake, and precipitation.

\begin{tabular}{|c|c|c|c|c|c|c|c|c|c|c|c|c|}
\hline & Jan & Feb & Mar & Apr & May & Jun & Jul & Aug & Sep & Oct & Nov & Mean \\
\hline $\begin{array}{l}\text { Grass, } \% \text { in diet } \\
\text { Selection index }\end{array}$ & & $\begin{array}{l}46 b^{1} \\
-0.3\end{array}$ & & $\begin{array}{l}49 b \\
-1.1\end{array}$ & & & $\begin{array}{r}74 \mathrm{a} \\
1.6\end{array}$ & $\begin{array}{l}69 a \\
-0.9\end{array}$ & & $\begin{array}{c}75 a \\
0.3\end{array}$ & $\begin{array}{l}77 \mathrm{a} \\
-0.7\end{array}$ & 64 \\
\hline $\begin{array}{l}\text { Forbs, \% in diet } \\
\text { Selection index }\end{array}$ & & $\begin{array}{r}44 \mathrm{a} \\
0.1\end{array}$ & & $\begin{array}{l}15 b \\
-4.4\end{array}$ & & & $\begin{array}{r}4 c \\
-8.0\end{array}$ & $\begin{array}{r}3 c \\
-5.9\end{array}$ & & $\begin{array}{l}9 \mathrm{bc} \\
-2.5\end{array}$ & $\begin{array}{r}2 c \\
-4.7\end{array}$ & \\
\hline $\begin{array}{l}\text { Browse, } \% \text { in diet } \\
\text { Selection index }\end{array}$ & & $\begin{array}{r}10 \mathrm{c} \\
0.7\end{array}$ & & $\begin{array}{r}38 \mathrm{a} \\
9.5\end{array}$ & & & $\begin{array}{c}23 \mathrm{bc} \\
4.0\end{array}$ & $\begin{array}{c}28 \mathrm{ab} \\
7.4\end{array}$ & & $\begin{array}{r}12 \mathrm{c} \\
4.5\end{array}$ & $\begin{array}{l}15 \mathrm{bc} \\
4.5\end{array}$ & \\
\hline $\mathrm{CP}, \%$ in diet & & 15 & & 18 & & & 13 & 10 & & 9 & 11 & 13 \\
\hline $\begin{array}{l}\text { Dry matter intake } \\
\mathrm{g} / \mathbf{k W ~ B W} .75\end{array}$ & & 97 & & 111 & & & 95 & 54 & & 77 & 92 & \\
\hline $\begin{array}{l}\text { Precipitation, mm, } 1981 \\
\text { Median, 1919-1984 }\end{array}$ & $\begin{array}{l}16 \\
14\end{array}$ & $\begin{array}{l}24 \\
22\end{array}$ & $\begin{array}{r}108 \\
21\end{array}$ & $\begin{array}{l}87 \\
35\end{array}$ & $\begin{array}{l}72 \\
65\end{array}$ & $\begin{array}{c}151 \\
66\end{array}$ & $\begin{array}{r}0 \\
35\end{array}$ & $\begin{array}{l}90 \\
37\end{array}$ & $\begin{array}{l}21 \\
57\end{array}$ & $\begin{array}{r}118 \\
45\end{array}$ & $\begin{array}{r}0 \\
21\end{array}$ & \\
\hline
\end{tabular}

${ }^{1}$ Means within rows followed by the same letter are not significantly different $(P>0.05)$.

Forb selection differed $(P<.05)$ among collection periods (Table 2). Selection values were negative except in February, although forbs generally have high selection values. However, in this study noxious weeds represented a high percentage of the forb component. While forbs as a class were fairly unpalatable, certain species were highly selected. Orange zexmenia is a good example of this. It represented a very small percentage of the available vegetation, but was utilized heavily by goats throughout the growing season.

Browse averaged $21 \%$ of the diets of goats during the year. Bryant (1977) and Malechek (1970) reported goats consumed 40 and $39 \%$ browse, respectively, on the Sonora Research Station. However, browse had higher selection values than grass or forbs (Table 2). This might indicate that goats would have selected more browse had it been more available. However, observations of live oak and shin oak (Quercus pungens) - the major browse species selected-indicated that utilization was always moderate. Goats selected 38\% browse in April and 28\% in August compared to 10 and $12 \%$ in February and October, respectively.

Acorns were only available during October and November when they were selected by the goats. Acorns contributed 6 and $9 \%$ to the diets in pasture 1 in October and November, respectively, and 4\% to diets in pasture 2 in the month of November, with an overall average consumption of $2 \%$.

We found no significant daily variation in diet selection within collection periods. Theoretically, as forage was removed by the 44 animal units of livestock, the preferred plants would decrease and the cannulated goats would have to modify their diet selection. However, there were no differences among days within grazing periods in the proportion of grass, forbs, browse, or acorns in their diet, whether the cannulated goats were grazing with or separated from the herd. Apparently goats have certain physical characteristics (i.e., bipedal grazing stance, upper mobile lip, and prehensile tongue) that provide them with the necessary foraging skills to select preferred forages even at excessive grazing pressures.

The grazing pressure index in the paddocks grazed by the herd varied from .53 in February to .27 in July with an average of .41 for the study period (Table 1). Average yearlong GPI of .25 is considered a moderate level for rangelands of the Edwards Plateau of Texas (Ralphs 1983). Previous research has indicated that goat production is less affected by heavy grazing pressures than cattle and sheep (Taylor and Merrill 1986).

\section{Chemical Analysis of Diets}

Mean crude protein (CP) of diets (Tables 1 and 2) was slightly higher than Bryant (1977) reported for Spanish and Angora goats. Crude protein varied seasonally from a high of $18 \%$ in April to $9 \%$ in October (Table 2). Generally, higher CP values tended to be associated with larger amounts of browse and forbs in the diet. Average CP levels in paddocks 1 and 2 were not significantly different, even though significant differences in grass and browse selection were measured between these 2 pastures.

During August, October, and November, $\mathrm{CP}$ levels in goat diets dropped to near the $9 \%$ minimum level recommended for Angora goats (Huston et al. 1971). During these 3 periods the goat selected large amounts of grass and small amounts of forbs and browse.

Crude protein values did not differ $(P<.05)$ among days with grazing periods. This was expected for the pasture that was void of livestock; however, the presence of 44 animal units ( 2.7 animal units $/ \mathrm{ha}$ ) in the grazed pasture was expected to elicit some changes in CP level among days. Intensity and frequency of precipitation probably helped buffer the effects of the high grazing pressures for this study, but the foraging efficiency of goats was another important factor.

Average IVOMD was $64 \%$ across collection periods. Digestibility was highest in April (72\%) and lowest in August (59\%) (Table 1). Digestibility values did not differ significantly among days within collection periods. Although IVOMD seemed to be more sensitive to changing forage conditions than CP values, IVOMD did not change significantly from one day to the next.

Crude protein and digestibility did not respond the same across collection periods (Table 2). This can partially be explained by the selection of acorns in October and November. Acorns are rather low in CP (approximately 6\%) but high in digestibility (approximately $70 \%$ ). The most difficult collection period to explain was the February period. Forbs represented $43 \%$ of the goat's diets at this time and dietary $\mathrm{CP}$ values averaged $14.8 \%$ with a corresponding digestibility of $62 \%$. Higher digestibility values would be expected for this high level of forb consumption. However, digestibility was probably reduced by higher than usual consumption of mature grass. The protein level during February was more than adequate for the production requirements of a $31.8 \mathrm{~kg}$ female Angora nannie, but the energy level was marginal for maintenance (Huston et al. 1971).

Fecal output varied from a low of $317 \mathrm{~g}$ of DM/d in August to a high of $\mathbf{4 0 7} \mathrm{g}$ in November. Low fecal weights were associated with hot dry weather and mature forage. Diets at the lowest fecal output contained $62 \%$ grass and $34 \%$ browse. The highest fecal output occurred when diets contained $72 \%$ grass, $18 \%$ browse, and $9 \%$ acorns and $C P$ and IVOMD values were 10 and $65 \%$, respectively.

Dry matter intake in August was lower than in any other collection period (Table 2). Dietary levels of CP and IVOMD also were low in August. This was the only collection period during which almost no regrowth was available. Not only was this period represented by poor forage quality, but due to the hot weather, the goats 
were less willing to actively graze during the heat of the day. Precipitation after the August collection increased the regrowth of warm-season perennial grass; and consequently goats increased selection of grass in their diets from $69 \%$ in August to $75 \%$ in October (Table 2).

Dry matter intake averaged $1,019,1,058$, and $1,020 \mathrm{~g} /$ day/goat on days 2,3 , and 4 , respectively. These data show that there was very little difference in nutrient intake of goats between days within a 4-day grazing period under SDG. We concluded for this particular stocking rate that grazing pressure during each 4-day grazing period had little effect on goat nutrition. This further supports the hypothesis that goats are opportunistic foragers and can select high quality diets even under conditions of heavy grazing pressure.

Even though nutrient intake of Angora goats remained at acceptable levels before and during the breeding season, kid production for the subsequent kidding season, measured in terms of percent kid crop raised (50\%), was less than optimum. The poor reproductive performance of the Angora goats apparently resulted from factors other than diet quality or quantity.

\section{Literature Cited}

Anderson, C.M., and M.M. Kothmann. 1982. A two-step sampling technique for estimating standing crop of herbaceous vegetation. J. Range Manage. 35:675.

A.O.A.C. 1970. Official methods of analysis (11th ed.) Assoc. Off. Agr. Chem. Washington, D.C.

Bryant, F.C. 1977. Botanical and nutritive content in diets of sheep, Angora goats, Spanish goats, and deer grazing a common pasture. PhD. Diss. Texas A\&M Univ. College Station.
Durham, A.J., Jr., and M.M. Kothmann. 1977. Forage availability and cattle diets on the Texas Coastal prairie. J. Range Manage. 30:103-106. Huston, J.E., M. Shelton, and W.E. Ellis. 1971. Nutritional requirements of the Angora goat. Tex. Agr. Exp. Sta. Bull. 1105.

Malechek, J.C. 1970. The botanical and nutritive composition of goat diets on lightly and heavily grazed ranges in the Edwards Plateau of Texas. Ph.D. Diss. Texas A\&M Univ. College Station.

Merrill, L.B., and C.A. Taylor. 1975. Advantages and disadvantages of intensive grazing management systems near Sonora and Barnhart. Rangeland Resources. 1971-74. Cons. PR 3341. p 10-11.

Ralphs, M.H. 1983. Vegetation and livestock response to increasing stocking rates in a simulated short-duration grazing system. Ph.D. Diss., Texas A\&M Univ., College Station.

Savory, A. 1979. Ranch fencing designs for short-duration grazing. Beef Cattle Sci. Handbook. 16:380-383.

Scarnecchia, D.L. and M.M. Kothmann. 1982. A dynamic approach to grazing management terminology. J. Range Manage. 35:262-264.

Smeins, F.E., T.W. Taylor, and L.B. Merrill. 1976. Vegetation of a 25 year exclosure on the Edwards Plateau of Texas. J. Range Manage. 29:24.

Steel, R.G.D., and J.H. Torrie. 1980. Principles and procedures of statistics. Second Edition. McGraw-Hill, New York.

Taylor, C.A., M.M. Kothmann, L.B. Merrill, and D. Elledge. 1980. Diet selection by cattle under high-intensity, low-frequency, short duration, and Merrill grazing systems. J. Range Manage. 33:428-434.

Taylor, C.A., and L.B. Merrill. 1986. Cattle, sheep, and goat production from fixed yearlong stocking rates. Texas Agr. Exp. Sta. CPR-44164457.

Van Soest, P.J., and R.H. Wine. 1967. Use of detergents in the analysis of fibrous feed. I.V. The determination of plant cell-wall constituents. J. Assoc. Off. Anal. Chem. 50:314.

\title{
Call for Papers \\ IVth INTERNATIONAL RANGELAND CONGRESS
}

\author{
22-26 April 1991 \\ Montpellier, France
}

The IVth INTERNATIONAL RANGELAND CONGRESS will convene in MONTPELLIER (FRANCE), under the aegis of AGROPOLIS (International Complex for Research and Higher Education) and the ASSOCIATION FRANÇAISE de PASTORALISME (AFP-French Association for Range Management).

The official languages of the IVth IRC will be French and English; permanent simultaneous translation will be available, including during field trips.

The Scientific Committee wishes to emphasize issues related to the mediterranean and subtropical isoclimatic zones, but other subjects will be addressed. In particular, general issues of methodologies and management techniques and problems pertaining to other ecoclimatic zones are envisaged.

Registration fees are 2500 FF (approx. 400 US\$) before Oct. 31, 1990 for full members and 1500 FF (approx. 250 US\$) for associate members.

Deadlines for contributions are as follows:

* Title and 50-100 words synopsis : March 31, 1990

* 500-word summary : May 31, 1990

* Full paper (4 pages of Journal of Range Management, i.e. approx 4000 words): July 31, 1990

For further information on the IVth IRC, please contact:

Dr. H.N. Le Houérou, Chairman, Organizing Committee

IVth INTERNATIONAL RANGELAND CONGRESS

C.N.E.A.R.C.

PO Box 5098

F-34033 MONTPELLIER Cedex

France

Telex: $490549 \mathrm{~F} ; \quad$ Fax: (33) 67410232 